\title{
Analysis of Mathematical Proof Ability in Abstract Algebra Course
}

\author{
Nina Agustyaningrum ${ }^{1, *}$, Asmaul Husna', Yudhi Hanggara' ${ }^{1}$, Agus Maman Abadi², Ali Mahmudi² \\ ${ }^{1}$ Department of Mathematics Education, Universitas Riau Kepulauan, Indonesia \\ ${ }^{2}$ Department of Mathematics Education, Yogyakarta State University, Indonesia
}

Received November 16, 2019; Revised January 21, 2020; Accepted February 7, 2020

Copyright $\odot 2020$ by authors, all rights reserved. Authors agree that this article remains permanently open access under the terms of the Creative Commons Attribution License 4.0 International License

\begin{abstract}
Mathematical proving is an important ability to learn abstract algebra. Many students, however, found difficulties in solving problems involving mathematical proof. This research aims to describe the students' mathematical proving ability and to find out the difference of the ability among students in private universities with three different levels of accreditation - A, $\mathrm{B}$, and $\mathrm{C}$. We used descriptive and comparative methods to reach the goals by involving mathematics education department students from A, B, and C-accredited private universities as its subjects. We used a test and interview to collect the data. The data of the students' mathematical proving ability were then statistically described and then compared among the three subject categories using the Kruskal-Wallis test and U Mann Whitney post hoc test. The results suggest that the students' mathematical proving ability from the $\mathrm{A}, \mathrm{B}$, and $\mathrm{C}$-accredited universities respectively were 77.14 (high category), 39.32 (low category), and 36.78 (low category). Furthermore, the comparison results suggest that the significant differences only happen between universities with $\mathrm{A}$ and $\mathrm{B}$ accreditation level, and between the ones with $\mathrm{A}$ and $\mathrm{C}$ accreditation. Based on these findings, the mathematical proving ability of the students from B and $\mathrm{C}$-accredited universities still needs to be improved by making the students accustomed to exercising with proof problems, motivating them to learn, and providing them learning materials that are easy to understand.
\end{abstract}

Keywords Abstract Algebra, Accreditation of Private University, Comparison Analysis, Descriptive Analysis, Mathematical Proving Ability

\section{Introduction}

Mathematics is a deductive science that relies on logical thinking to prove the truth value of a preposition or a theorem. The truth value of a mathematics preposition or theorem could be acknowledged after being proven true based on the existing definitions, axioms, or theorems. Proof is the most important part of understanding mathematics clearly (Arnawa, 2006; Hanna, Jahnke, \& Pulte, 2010; Maya \& Sumarmo, 2011). Stylianides \& Stylianides (2008) argued that there are three reasons of why mathematical proof is important. First, the mathematical proving ability is very important for deep mathematics learning. Second, proficiency in mathematical proving can increase the students' mathematical abilities more. Third, many students encountered difficulties in mathematical proving.

A mathematical proof is a sequence of a logical statement which explains why a given preposition is true. Arnawa, Yerizon, \& Enita (2019) mentioned that a lecturer could use mathematical proof tasks to see how students can argue logically, how students use examples and non-examples to defend their opinions, how students might experience weaknesses in reasoning, and what kinds of misconceptions the students often experience.

In terms of proof in mathematics, Stout (2014) argued that a large portion of mathematics consists of proofs. Proof of a theorem is a finite sequence of claims. Each claim is derived logically from the previous claims as well as theorems whose truth has already been established. Besides, Stefanowicz (2014) stated that mathematics proof is absolute, which means that one a theorem is proven true, then it shall be true forever.

In many kinds of literature about proof and proving activities in mathematics education, there is a concept known as the construction of proof (Santosa, 2013). Selden \& Selden (2009) stated that the ability to construct proof includes the ability to use proving methods, definitions, lemmas, and theorems to show the truth value of a mathematics preposition. Ball et al. (2002) and Sriraman (2004) stated that the ability to construct proof is 
the ability to show agreement to the use of proving methods, resolutions, and theorems to prove the truth value of a statement. Construction of proof is a mathematical task when the person - in order to prove the given statement - is given some preliminary information (e.g., assumptions, axioms, resolutions) and is asked to apply methods of drawing conclusion (i.e., recalling established facts, applying theorems) until the desired conclusion is proven.

Although proof is the most important part of mathematics, proving is one of the difficult things to learn and to teach (Arnawa, 2006). Various previous researches suggest that there are still many students who found difficulties in constructing mathematical proofs (Selden \& Selden, 2003; Stylianides, Stylianides, \& Philippou, 2007; Ozdemir \& Ovez, 2012; Cyr, 2013; Guler, 2016; Arnawa, Yerizon, \& Enita, 2019). Furthermore, Yerizon (2011) also concluded that the students' mathematical proving ability was still low. At the tertiary education level, the mathematical proving ability is more formal and more accurate than at the elementary and secondary school level. This makes students, especially in mathematics and mathematics education department, have to read and practice more in writing mathematical proof.

Writing proofs in abstract algebra will be very different to writing proofs in calculus, geometry, or real analysis. The mathematical topics which become the proving contexts are very diverse, for example, abductive strategies in number theory course (Kusnandi, 2008), abstract algebra (Arnawa, 2006; Isnarto, 2014; Samparadja, 2014), calculus (Tucker, 1999), and real analysis (Yerizon, 2011). The topics of mathematics for university level, which become the object of - and cannot be separated from - proving research were dominated by continuous mathematics such as calculus, real analysis, number theory, and abstract algebra.

Abstract algebra is one of the mathematics courses that aims to develop mathematical proving ability (Isnarto, 2014). Proving is an important component in learning abstract algebra (Findel, 2001). This is because the topics in abstract algebra are full of definitions and theorems which all require proof. Therefore, the students are required to understand every definition and theorem they learn and be able to organize concepts in proving theorems.

Many factors affect the students' difficulty in proving activities, one of them is the learning experience. Their experience in working with mathematical proof tasks in high school will impact their proving ability in their first year of college. Knuth (2002) stated that one of the reasons why students encountered difficulties in proving was their experience in constructing proof. His research was limited to constructing proof in school geometry. Weber (2001) found that the initial cause of students' failure in proving was caused by a lack of strategic knowledge. Furthermore, many argued that the students could not determine whether the desired proof is valid or not (Moore, 1994; Hanna \& Jahnke, 1996; Barnard, 2000; Selden \& Selden, 2003; Arnawa, 2006; Kusnandi, 2008; Tall et al., 2011). Also, the students' negative perceptions of proof and proving activities greatly affect their ability to construct and to write the proofs.

Regarding the mathematical proof, Reid (2005) stated that proving makes mathematics unique and different from the other disciplines. Through the mathematical proving task, a lecturer can see: (1) how the students provide logical arguments, (2) how students use examples and non-examples to support their arguments, (3) kinds of students' weaknesses in reasoning experience, and (4) kinds of misconception the students often experience. Hart (1994) and Moore (1994) found that most students still encountered difficulties in mathematical proving in higher education, especially in abstract algebra. These phenomena also happened to students of the mathematics education department at Universitas Riau Kepulauan, Universitas Ahmad Dahlan, Universitas Pasir Pangaraian, and STKIP Insan Madani Air Molek, all of them are private higher education institutions in Indonesia. The students' learning results at the universities, as mentioned earlier, were not satisfactory. Therefore, we need to find out the students' mathematical proving ability in abstract algebra and the differences in terms of the ability to solving abstract algebra proving problems. The insights of this ability, as well as the difficulties experienced by the students in mathematical proving, could be a useful source to seek the appropriate solution. In the end, it could be reached a better learning result.

\section{Materials and Method}

\subsection{Research Approach}

This research used a descriptive quantitative approach and continued by comparative analysis. The descriptive analysis was used to describe the test results and the level of mathematical proving ability of the students, while the comparative analysis was used to determine the differences in mathematical proving ability of the students grouped by their institutions' accreditation ranking.

\subsection{Research Subjects}

We involved three groups of students coming from private universities in Indonesia. The first group consisted of 35 students from an A-accredited (outstanding) university - Universitas Ahmad Dahlan, Yogyakarta. The second group consisted of 32 students from B-accredited (very good) university - Universitas Riau Kepulauan, Batam. The third group consisted of 29 students from $\mathrm{C}$-accredited (good) university. They were 15 students from Universitas Pasir Pangaraian, Riau, and 14 students 
from STKIP Insan Madani Air Molek, Riau.

\subsection{Research Instruments}

To get the data of students' mathematical proving ability, we administered a test instrument measuring the mathematical proving ability. The test consisted of three essay problems in the topic of group theory. Further, to get additional information about the difficulties experienced by the students in solving abstract algebra proving problems, we conducted interviews with six students as the representatives of the research subjects from the three groups of universities.

\subsection{Data Analysis Technique}

Based on the research goals, we run two kinds of data analysis - descriptive statistical analysis and comparative analysis. The test results - the quantitative data - were analyzed by scoring 0 to 4 for each item with criteria as follows (Arnawa, Yerizon, \& Enita, 2019). Score 0 was given if there is no proving process at all, score 1 was given if the students could make one approach but incorrect, score 2 was given if there is a substantial progress, score 3 was given if the solution is obtained with minor fallacy, and score 4 if the students could make a completion of proving process. The total score was then converted into 0 to 100 scale. The results were then descriptively analyzed, and the mean of them was categorized using a guideline presented in Table 1 (Maya \& Sumarmo, 2011).

Table 1. Level category of mathematical proving ability

\begin{tabular}{|c|c|}
\hline Category & Mathematical Proving Ability Score Interval \\
\hline High & $70 \leq \mathrm{X} \leq 100$ \\
\hline Intermediate & $55 \leq \mathrm{X}<70$ \\
\hline Low & $0 \leq \mathrm{X}<55$ \\
\hline
\end{tabular}

$\mathrm{X}$ : Mathematical proving ability score

Furthermore, to find out whether there are differences in the mathematical proving ability of the students based on their university accreditation ranking, we used independent $\mathrm{k}$-sample comparative analysis. The independent $\mathrm{k}$-sample comparative test in this research was carried out using the Kruskal-Wallis non-parametric statistical test because the normality assumption on the data gained was not fulfilled. Meanwhile, a further test was carried out using the non-parametric statistical Mann-Whitney U test.

\section{Results}

The data of this research were the mathematical proving ability in abstract algebra course. The data analysis was divided into two parts - the descriptive statistical analysis used to describe mathematical proving ability and the comparative analysis to see differences of mathematical proving ability based on the university accreditation ranking.

\subsection{Descriptive Analysis Results}

The mathematical proving test results were analyzed by scoring 0 to 4 for each item according to the given criteria (Arnawa, Yerizon, \& Enita, 2019), then the total score was converted into 0 to 100 scale. The results were presented in Table 2.

Table 2. The mathematical proving ability test results

\begin{tabular}{|l|c|c|c|}
\hline \multirow{2}{*}{ Statistical Descriptive } & \multicolumn{3}{|c|}{ University Accreditation Level } \\
\cline { 2 - 4 } & $\mathrm{A}$ & $\mathrm{B}$ & $\mathrm{C}$ \\
\hline Mean & 77.14 & 39.32 & 36.78 \\
\hline Median & 83.33 & 33.33 & 41.67 \\
\hline Mode & 83.33 & 33.33 & 41.67 \\
\hline Deviation standard & 12.68 & 18.66 & 11.25 \\
\hline Variance & 160.72 & 359.47 & 126.57 \\
\hline Max. score & 91.67 & 91.67 & 58.33 \\
\hline Min. score & 50 & 16.67 & 16.67 \\
\hline Max. Teoritic score & 100 & 100 & 100 \\
\hline Min. Teoritic score & 0 & 0 & 0 \\
\hline
\end{tabular}

From Table 2, the highest mean of mathematical proving ability score was the A-accredited group (77.14), followed by the B-accredited group (39.32), and the lowest mean score was $\mathrm{C}$-accredited group (36.78). In this case, the score of $\mathrm{B}$ and $\mathrm{C}$ accreditation groups were still far below the maximum score. The deviation standard of the $\mathrm{A}, \mathrm{B}$, and $\mathrm{C}$ scores were respectively $12.68,18.66$, and 11.25. We can see that the deviation standard of Group B was the highest. It indicated that the distribution of data on Group B was quite far from the average. Meanwhile, the highest score achieved by the students in Group C was only 58.33. This score was much smaller when compared to the highest score achieved by Group A and Group B (91.67).

From the scores gained, we categorized the students' mathematical proving ability into three categories - high, intermediate, low - based on the criteria in Table 1. The result is presented in Table 3.

From Table 3, we can see that the most of students of A-accredited university performed high ability $(77.14 \%)$, while most of the students of B- and C-accredited universities performed low (respectively $87.5 \%$ and 96.5\%). Moreover, none of the students in C-accredited university performed high ability. This phenomenon indicated that the mathematical proving ability of the students in B- and C-accredited universities were still poor.

Furthermore, to obtain more detailed information about the mathematical proving ability, we analyzed the score obtained for each test item based on the accreditation group, as presented in Table 4. 
Table 3. Test score distribution based on mathematical proving ability category

\begin{tabular}{|c|c|c|c|c|c|c|c|}
\hline \multirow{2}{*}{ Category } & \multirow{2}{*}{ Score Interval } & \multicolumn{2}{|c|}{ A-accredited Institution } & \multicolumn{2}{c|}{ B-accredited Institution } & \multicolumn{2}{|c|}{ C-accredited Institution } \\
\cline { 3 - 8 } & & Number & $\%$ & Number & $\%$ & Number & $\%$ \\
\hline High & $70 \leq \mathrm{X} \leq 100$ & 27 & 77.14 & 4 & 12.5 & 0 & 0 \\
\hline Intermediate & $55 \leq \mathrm{X}<70$ & 5 & 14.29 & 0 & 0 & 1 & 3.45 \\
\hline Low & $0 \leq \mathrm{X}<55$ & 3 & 8.57 & 28 & 87.5 & 28 & 96.55 \\
\hline \multicolumn{2}{|c|}{ Total } & 35 & 100 & 32 & 100 & 29 & 100 \\
\hline
\end{tabular}

Table 4. Average score of each item of mathematical proving test

\begin{tabular}{|c|c|c|c|c|}
\hline \multirow{2}{*}{ Accreditation } & \multicolumn{3}{|c|}{ Item Number } & \multirow{2}{*}{ Mean } \\
\cline { 2 - 5 } & 1 & 2 & 3 & 77.14 \\
\hline A & 72.86 & 88.57 & 70 & 39.32 \\
\hline B & 50 & 28.91 & 39.06 & 36.78 \\
\hline C & 56.03 & 30.17 & 24.14 & 51.08 \\
\hline
\end{tabular}

Table 5. Score distribution of the mathematical proving ability test

\begin{tabular}{|c|c|c|c|c|c|c|c|c|c|c|c|c|c|c|c|c|}
\hline \multirow{3}{*}{ Item Number } & \multicolumn{15}{|c|}{ Respondent Frequency } & \multirow{3}{*}{ Total } \\
\hline & \multicolumn{3}{|c|}{ Score 0} & \multicolumn{3}{|c|}{ Score 1} & \multicolumn{3}{|c|}{ Score 2} & \multicolumn{3}{|c|}{ Score 3} & \multicolumn{3}{|c|}{ Score 4} & \\
\hline & A & B & $\mathrm{C}$ & A & B & $\mathrm{C}$ & A & B & $\mathrm{C}$ & A & B & $\mathrm{C}$ & A & B & $\mathrm{C}$ & \\
\hline 1 & 0 & 0 & 0 & 0 & 8 & 1 & 4 & 20 & 21 & 30 & 0 & 6 & 1 & 4 & 1 & 96 \\
\hline 2 & 0 & 4 & 4 & 2 & 23 & 20 & 5 & 3 & 0 & 0 & 0 & 5 & 28 & 2 & 0 & 96 \\
\hline 3 & 0 & 1 & 15 & 4 & 16 & 0 & 3 & 12 & 14 & 24 & 2 & 0 & 4 & 1 & 0 & 96 \\
\hline Total & 0 & 5 & 19 & 6 & 47 & 21 & 12 & 35 & 35 & 54 & 2 & 11 & 33 & 7 & 1 & 288 \\
\hline
\end{tabular}

Based on Table 4, the level of difficulty for every group varied in order. But overall, the most difficult item was Number 3, followed by Number 2, and the last was Number 1. To see the difficulties encountered by the students, Table 5 presents the frequency distribution of the gained score for each group.

Based on the score distribution in Table 5, in Group A, 28 students successfully answered Number 2 with score 4 , while Number 1 was only answered correctly by 1 student, and Number 3 was answered correctly by 4 students. In Group B, score 4 was obtained by 4 students for problem Number 1, 2 students for question Number 2, and only 1 student for question Number 3. Meanwhile, in group $\mathrm{C}$, only 1 student received score 4 for question Number 1 and no student answered correctly for questions Number 2 and 3 .

\subsection{Comparative Analysis}

We used the Kruskal-Wallis non-parametric statistical test to test the differences in mathematical proving ability among the groups A, B, and C. The use of non-parametric statistical test was carried out because the research data obtained were not normally distributed. The results of normality tests conducted using the Kolmogorov-Smirnov test are presented in Table 6.

From the results of the normality test, it was concluded that the data from the three sample groups were not normally distributed. Thus, to find out the differences in their mathematical proving abilities, non-parametric statistical test was used - the Kruskal-Wallis test. The results of the Kruskal Wallis test conducted using SPSS software as presented in Table 7. 
Table 6. Normality test of mathematical proving ability data

\begin{tabular}{|c|c|c|c|c|c|}
\hline Accreditation Group & $\mathrm{N}$ & K-S $(\mathrm{Z})$ & Sig. & Decision & Conclusion \\
\hline A & 35 & 0.402 & 0.000 & $\mathrm{H}_{0}$ rejected & Not normally distributed \\
\hline B & 32 & 0.294 & 0.000 & $\mathrm{H}_{0}$ rejected & Not normally distributed \\
\hline C & 29 & 0.289 & 0.000 & $\mathrm{H}_{0}$ rejected & Not normally distributed \\
\hline
\end{tabular}

$\mathrm{H}_{0}$ : Data were normally distributed

Table 7. Results of Kruskal-Wallis test

\begin{tabular}{|c|c|c|c|c|}
\hline Accreditation Group & Chi-Square & Df & Sig & Decision \\
\hline A, B, C & 56.33 & 2 & 0.000 & H $_{0}$ rejected \\
\hline
\end{tabular}

$\mathrm{H}_{0}$ : There is no significant difference in mathematical proving ability among students from $\mathrm{A}, \mathrm{B}$, and $\mathrm{C}$-accredited universities.

From Table 7, we can see that the probability value (Sig) based on the Kruskal Wallis test was 0.00 smaller than 0.05 . It can be concluded that there were significant differences in mathematical proving ability between groups A, B, and C. To find out which accreditation groups has significant differences to the mathematical proving ability, the post hoc testing was done with the Mann Whitney $U$ test. The summary of the test result is presented in Table 8.

Table 8. Mann Whitney $U$ test results

\begin{tabular}{|c|c|c|c|}
\hline $\begin{array}{c}\text { Groups to } \\
\text { Compare }\end{array}$ & $\begin{array}{c}\text { Mann-Whitney } \\
\text { U }\end{array}$ & $\begin{array}{c}\text { Sig. } \\
\text { (2-tailed) }\end{array}$ & Result \\
\hline A dan B & 86.00 & 0.000 & Significant \\
\hline A dan C & 11.50 & 0.000 & Significant \\
\hline B dan C & 430.00 & 0.612 & Not-Significant \\
\hline
\end{tabular}

Based on the results of the Mann Whitney $U$ test in Table 8, it can be seen that the probability value (Sig.) for the test between accreditation group $\mathrm{A}$ and $\mathrm{B}$ and between $\mathrm{A}$ and $\mathrm{C}$ were smaller than the significance level of 0.05 . It means that there were significant differences in mathematical proving ability between group $\mathrm{A}$ and $\mathrm{B}$ as well as between A and C. Meanwhile, between group B and $\mathrm{C}$, the probability value (Sig.) was greater than the significance level of 0.05 . It means that there was no significant difference in mathematical proving ability between group $\mathrm{B}$ and $\mathrm{C}$.

\section{Discussion}

\subsection{Description of Mathematical Proving Ability}

Based on the results of this study, the students' mathematical proving ability in the A-accredited university was in the high category with an average score of 77.14, while the students' ability in the B- and $\mathrm{C}$-accredited were in the low category with an average score of 39.32 and 36.78 respectively. Therefore, the mathematical proving ability was in line with the institution accreditation ranking. Furthermore, to describe and to examine the constraints experienced by students in working on mathematical proof problems, Table 9 presents the distribution of scoring results on a scale of 0 to 4 on each question for each group.

Table 9. Distribution of scoring results in A-accredited university

\begin{tabular}{|c|c|c|c|c|c|c|}
\hline \multirow{2}{*}{ Number } & \multicolumn{5}{|c|}{ Frequency } & \multirow{2}{*}{ Total } \\
\cline { 2 - 6 } & $\begin{array}{c}\text { Score } \\
0\end{array}$ & $\begin{array}{c}\text { Score } \\
1\end{array}$ & $\begin{array}{c}\text { Score } \\
2\end{array}$ & $\begin{array}{c}\text { Score } \\
3\end{array}$ & $\begin{array}{c}\text { Score } \\
4\end{array}$ & \\
\hline 1 & 0 & 0 & 4 & 30 & 1 & 35 \\
\hline 2 & 0 & 2 & 5 & 0 & 28 & 35 \\
\hline 3 & 0 & 4 & 3 & 24 & 4 & 35 \\
\hline Total & 0 & 6 & 12 & 54 & 33 & 105 \\
\hline
\end{tabular}

From Table 9, the distribution of students in group A got the most score of 3 and 4 . Towards problem number 2, most students got score of 4 compared to the other two problems which were only 4 students for problem number 3 and only 1 student for question number 1 . Meanwhile, if it is viewed from the average score (See Table 4), the most difficult problem for the students in the A-accredited group was question number 3 with an average of 70 , followed by question number 1 with an average of 72.86 . For question number 2 , the average score was 88.57 with 28 out of 35 students $(80 \%)$ could answer the questions correctly as there was no significant issue with the proving activities.

At the problem Number 1, the students were asked, "Investigate if $\mathrm{G}$, a set of rational number $Q$ with * operation, is a commutative group where the * operation is defined by $a * b=a+b+2 a b, \forall a, b \in Q$."

The problem 1 required a simple proving using initial concept of commutative group. There are 5 axioms that must be fulfilled in this proof - closed within the given operation, associative property, the existence of the identity element, the existence of the inverse element, and commutative property. Most students from the group A could prove these axioms correctly, but the most errors made were when determining the identity and inverse elements. Another error found in proving the inverse axiom is that the students forgot the requirement of inverse existence in a group. For example, we found that they forgot the characteristic of the inverse of $\mathrm{G}$ might be in the form of fraction which should not have zero as its denominator. Thus, there is one element of $\mathrm{G}$ that has no inverse, the 0.5. This causes $G$ is not categorized as a group. However, most students concluded that $G$ is a group as shown in Figure 1. 


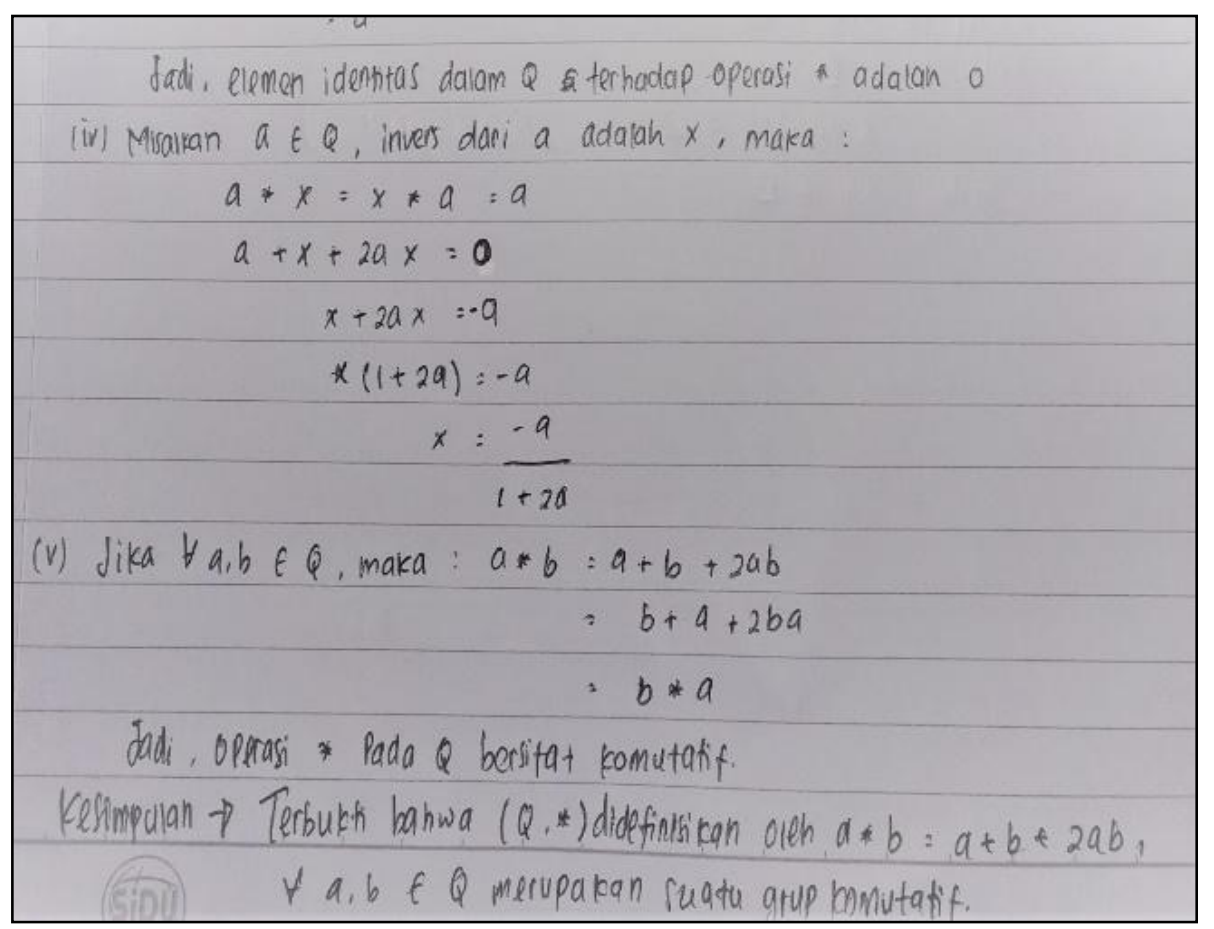

Figure 1. The sample of student's incorrect answer to problem 1

Further, we examined problem number 3 regarding subgroup proving. The most common errors found was that the students forgot to write the requirement that the subgroup must be a non-empty subset of the group. Another type of error found was that the students incorrectly applied the subgroup theorem. These findings are in line with the results of research reported by Moore (1994), Asiala et al. (1997), Harel (2007), and Weber (2001).

The second investigation was for the B-accredited group. Their score distribution is presented in Table 10.

Table 10. Distribution of scoring results in B-accredited university

\begin{tabular}{|c|c|c|c|c|c|c|}
\hline \multirow{2}{*}{ Number } & \multicolumn{5}{|c|}{ Frequency } & \multirow{2}{*}{ Total } \\
\cline { 2 - 6 } & $\begin{array}{c}\text { Score } \\
0\end{array}$ & $\begin{array}{c}\text { Score } \\
1\end{array}$ & $\begin{array}{c}\text { Score } \\
2\end{array}$ & $\begin{array}{c}\text { Score } \\
3\end{array}$ & $\begin{array}{c}\text { Score } \\
4\end{array}$ & \\
\hline 1 & 0 & 8 & 20 & 0 & 4 & 32 \\
\hline 2 & 4 & 23 & 3 & 0 & 2 & 32 \\
\hline 3 & 1 & 16 & 12 & 2 & 1 & 32 \\
\hline Total & 5 & 47 & 35 & 2 & 7 & 96 \\
\hline
\end{tabular}

From Table 10, we found that the most common error happened at item number 2 . This is in line with the results presented in Table 4 that the lowest score of this group was also number 2 (28.91), followed by score of number 3 (39.06). The problem number 2 said, "If $G$ is a group, $a \in$ $G, a$ is called idempotent if $a^{2}=a$. Examine the truth value of the following statement, 'If $a$ is an idempotent element of $G$, then $a$ is an identity element.' Explain your answer using an adequate proof." Problem 2 required the students to think in abstract way and to connect the previous axioms and theorems to prove the statement.
Figure 2 and Figure 3 are examples of the students' answer.

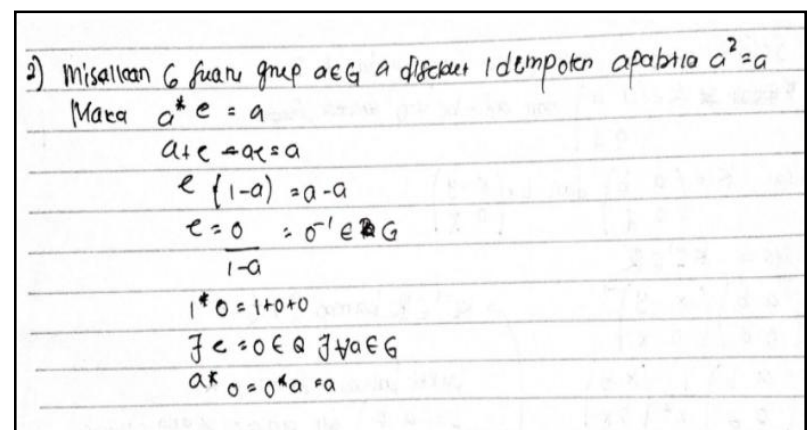

Figure 2. The sample of student's incorrect answer to problem 2

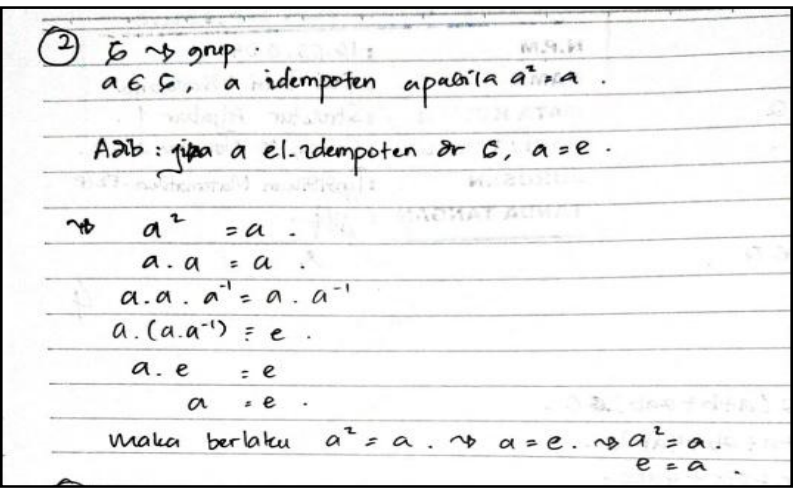

Figure 3. The sample of student's correct answer to problem 2

In Figure 2, the concept used by the student was not appropriate to prove problem number 2 . This indicated that the student was unable to connect the existing axioms 
and theorems to prove a new mathematical statement. Weber \& Alcock (2004) argued that students often have difficulty in constructing concrete representations of abstract concepts from group theory. Meanwhile, the correct answer can be seen in Figure 3, where this work was from the student with high ability.

Moreover, for problem 3, only 1 student could answer correctly though the concept required to answer the problem 3 has been learned by all of students and the lecturer also has taught this topic repeatedly to strengthen the subgroup concept retention. Problem number 3 said, "Given $\mathfrak{R}$ is a set of real number. We define

$$
K=\left\{\left(\begin{array}{ll}
a & b \\
c & d
\end{array}\right) \mid a, b, c, d \in \mathfrak{R}, a d-b c \neq 0\right\}
$$

with operation of multiplication on matrices is a group. Investigate if

$$
L=\left\{\left(\begin{array}{cc}
x & -y \\
y & x
\end{array}\right) \mid x, y \in \mathfrak{R}, x^{2}+y^{2} \neq 0\right\}
$$

is subgroup of $\mathrm{K}$."

The sample of the students' answer is presented in Figure 4.

Problem number 3 required the students understanding to use theorems in subgroup proving. The selected concept was correct, but the application shows that the students have not understood the concepts well. This phenomenon also happened in various research (Maharaj, 2010; Syaiful, Marsal, \& Kamid, 2016; Agustyaningrum et al, 2018; Yerizon et al, 2019). At the beginning, the student wrote $K \neq 0$ and is subset of A, it should be $L \neq$ $\emptyset$ and $L \subseteq K$. The next step was also incorrect, they wrote $A B^{-1} \in \mathfrak{R}$, it should be $A B^{-1} \in L$. The operation of multiplication on matrices was also incorrect. These findings confirmed that the students have not understood the concepts of subgroup proving and the initial concept of matrices operation.

The next investigation was for the $\mathrm{C}$-accredited group. Their score distribution is presented in Table 11.

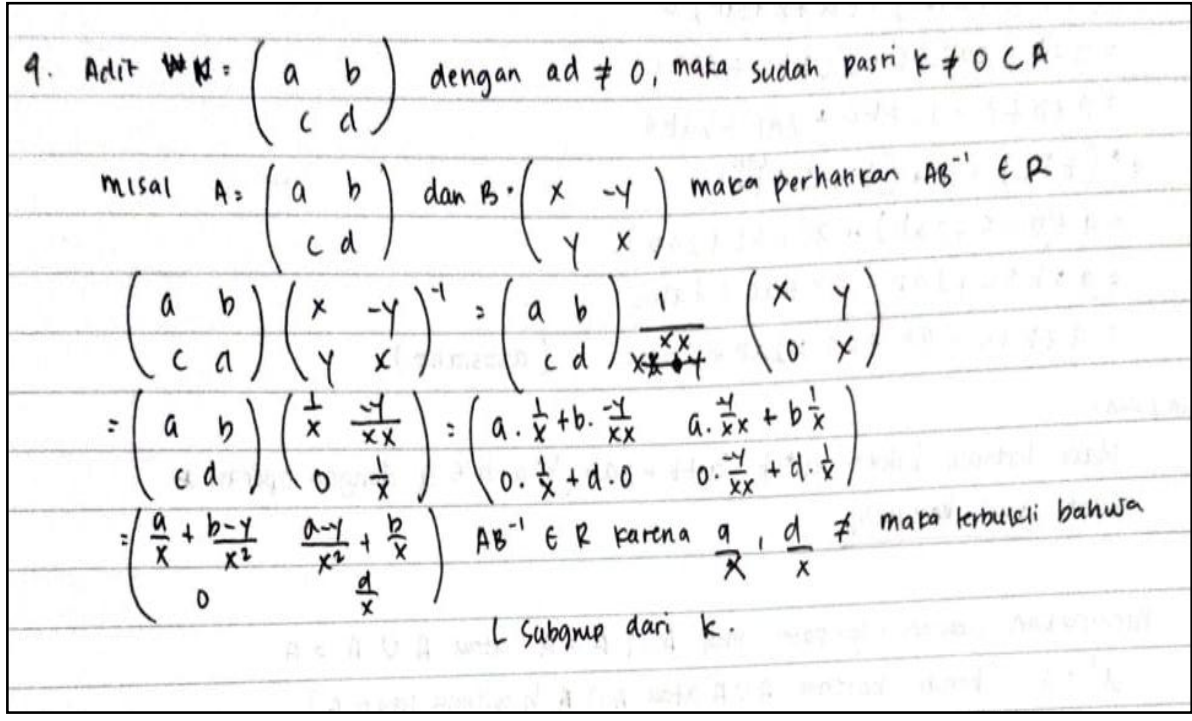

Figure 4. The sample of student's answer to problem 3 from group B

Table 11. Distribution of scoring results in C-accredited university

\begin{tabular}{|c|c|c|c|c|c|c|}
\hline \multirow{2}{*}{ Number } & \multicolumn{5}{|c|}{ Frequency } & \multirow{2}{*}{ Total } \\
\cline { 2 - 7 } & Score 0 & Score 1 & Score 2 & Score 3 & 1 & 29 \\
\hline 1 & 0 & 1 & 21 & 6 & 5 & 29 \\
\hline 2 & 4 & 20 & 0 & 0 & 0 & 29 \\
\hline 3 & 15 & 0 & 14 & 11 & 1 & 87 \\
\hline Total & 19 & 21 & 35 & & 0 & 29 \\
\hline
\end{tabular}




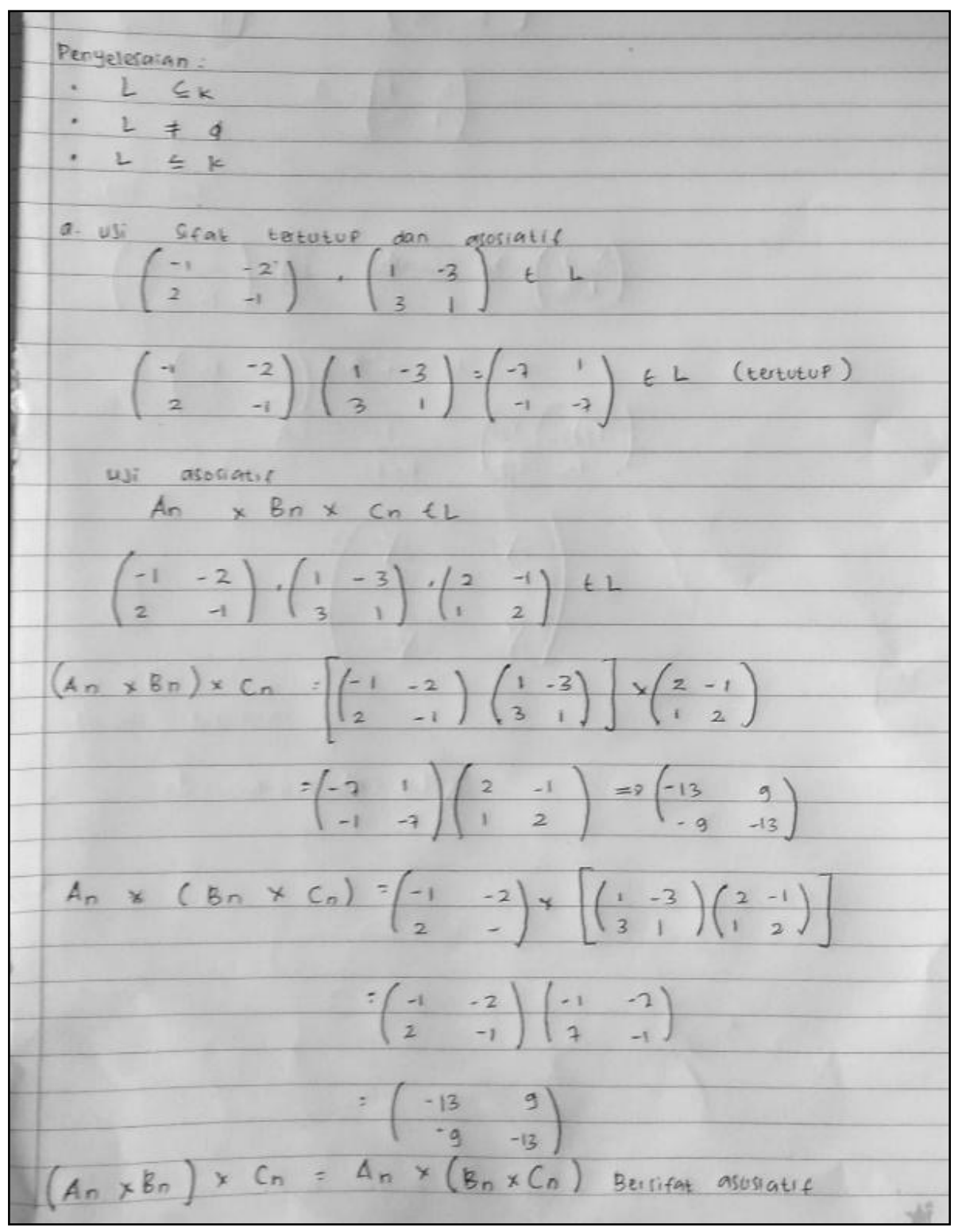

Figure 5. The sample of student's answer to problem 3 from group C

In the C-accredited university group, only 1 student correctly answered problem number 1 and none of the student answered correctly problems number 2 and 3 . The lowest score in problem 3 was 24.14 followed by problem 2 with a score of 30.17 and problem 1 with a score of 56.03 (See Table 4). The most common error found for solving problem 3 was that students proved subgroups by taking examples of numbers and not proving their general property. Figure 5 presents the sample of the students' incorrect answer.

Figure 5 shows that students prove the closed and associative property using counter example. This indicated that they could not understand the concepts and could not apply the existing concepts to solve the problem, either. This finding is in line with the opinion of Alcock \& Simpson (2002) who argued that, in solving abstract algebra proving problems, students often write their own intuitive arguments based on their conceptual description even though it is not valid.

After examining the errors happened in every group, we confirmed the causes of the errors to the students by conducting interviews. We selected 6 respondents as the representative of Group A, B, and C. Each respondent was questioned about the difficulty experienced in solving proving problems of abstract algebra. Six respondents said that abstract algebra was new topic that was different in characteristics from other subjects. Students were not yet familiar with the proving tasks and there were many unfamiliar terms which worsened the difficulty in understanding the concepts, which is abstract in nature. This is in line with the results of several studies (Leron \& Dubinsky, 1995; Carlson, 2003; Arnawa, 2006) which confirm that the difficulties in learning abstract algebra are usually caused by: (1) the concepts in abstract algebra 
are very abstract, (2) many examples relating to the concept are not well recognized by students, and (3) many students are not familiar with deductive proof. However, there were respondents from A-accredited group who said they felt challenged and were enthusiastic about this course.

As with respondents with low and intermediate ability, they felt that they would not be able to understand this material. One of them said,

"I don't know where to begin, or which theorem I should use when facing a proving task. I am confused to deal with matrices concept, too."

From the interview results, we got information that students also had constraints on initial knowledge. Also, the students in B and C-accredited universities complained about the inadequate handout availability. The handouts available were mostly in foreign language and difficult to understand. Another difficulty that occurred was that students could not identify assumptions that will be proven, unable to determine the initial steps and choose strategies to use in proving. This is in line with the opinion of Hart (1994), Weber (2001), Weber (2003), and Harel \& Sowder (2007) which stated that students commonly have difficulty in writing proof. The ability to validate the proof is a skill that is highly needed by students to develop and evaluate mathematical arguments and in order to successfully construct the proof they have to possess adequate understanding. The findings were also in line with what was reported by Moore (1994), that the difficulty of students in proving mathematics were unable to state the definition with their own words, too little intuition of understanding of a concept, inadequate concept images to write proof, lack of understanding on how to use definitions to get the whole proof structure and how to start proving.

The difficulties lead to the low quality of the students' understanding in abstract algebra as it was found in this study. Therefore, it is necessary to make the students accustomed to practicing mathematical proving tasks of abstract algebra in order to improve their level of thinking ability. Saefudin (2012) stated that making the students accustomed to practicing mathematical proving tasks and making conjectures before doing them will enable the students to deal with the proving tasks. Also, Fadilah \& Jamilah (2016) added that the learning process about mathematical proof should be displayed in the form of activities that facilitate the construction and reconstruction process of students' conceptual understanding. We also need to focus on strengthening the initial knowledge, because it greatly supports the students' understanding in learning mathematics as stated by Chamundeswari (2014). Another thing to support the mathematical proving ability of the students is to provide adequate handout to help them understand the topics. Enu et al. (2015) confirmed that the availability and use of handout in mathematics learning can improve the learning quality.

\subsection{Comparison of Mathematical Proving Ability}

The results of the comparison of mathematical proving ability in the students from A, B, and C-accredited university found that there were significant differences among the three groups. The significant differences were found between A and B and between A and C. Meanwhile, between $\mathrm{B}$ and $\mathrm{C}$, there was no significant difference. The average scores obtained in the groups $\mathrm{A}, \mathrm{B}$, and $\mathrm{C}$, respectively were $77.14,39.32$, and 36.78 . This score shows that the level of mathematical proving ability was in line with the accreditation ranking. This is also suitable with the purpose of higher education accreditation, which is to guarantee the quality of higher education. The accreditation of higher education institutions is an assessment activity to determine the eligibility of the higher education institutions such that the accreditation result could accurately reflect the quality of the institution. Moreover, Nguyen \& Ta (2017) argued that accreditation contributes significantly to improving the quality of teaching, learning, research, and university management.

From these findings, between groups $\mathrm{B}$ and $\mathrm{C}$, there was no significant difference in mathematical proving ability. The significant difference only occurred when they were compared to the group A. This was because the A-accredited university had better student input and adequate learning facilities compared to the B- and $\mathrm{C}$-accredited universities. This better input was due to the A-accredited university is more attractive for excellent students to enroll, as it has adequate learning facilities such as buildings, classrooms, complete learning media, laboratories, and libraries. These adequate learning facilities can create a conducive learning environment and process (Toraman et al., 2020) which in the end resulted in good learning results as well.

A different case happened in the $\mathrm{B}$ and $\mathrm{C}$-accredited universities. The universities had the same characteristics. They accommodate students who were failed to enroll to the A-accredited university. Therefore, the student input in these groups were not as good as the A-accredited university. The other similar characteristics were in terms of inadequate learning facilities in the $\mathrm{B}$ - and $\mathrm{C}$-accredited universities compared to the A-accredited one had. They did not have free internet services, they had limited reference books and journals in their libraries, inadequate learning media, and non-air conditioned classrooms which made the learning situation less comfortable. The interview results also confirmed that the problem of learning facilities and infrastructure has been complained by our respondents from the $\mathrm{B}$ and $\mathrm{C}$-accredited universities.

In addition to facilities and infrastructure issues, another characteristic of the B and C-accredited university was mentioned by Nisa (2018) who reported that the result of accreditation had a significant effect on students' learning intensity. The result of accreditation A motivates students to study diligently, and on the contrary, the 
students from B and C- accredited universities tend to have moderate and low intensity of learning. This was also confirmed by our research subjects in groups B and C. Therefore, lecturers need to work to improve the students' motivation to learn better, especially in solving mathematical proving tasks. Hamdi \& Abadi (2014) also reported that one of the efforts of lecturers to improve the students' mathematics learning achievement was to increase their motivation to learn.

These similar characteristics found in the B nd $\mathrm{C}$-accredited university groups made no significant difference in their students' mathematical proving ability. In the other words, it can be concluded that the ability of students in the $\mathrm{B}$ and $\mathrm{C}$-accredited universities were the same. The results of this study support the findings of Mairing (2016) who reported that the mathematical ability of students in A-accredited schools were higher than the B and $\mathrm{C}$-accredited schools, while the mathematical abilities of the students in B and C-accredited schools were not significantly different.

This similarity could also be seen from the results of this study which found that there was no significant difference in mathematical proving ability between $\mathrm{B}$ and $\mathrm{C}$-accredited groups with both the average scores were in the low category and the score difference was only 2.54 . However, the average score of the B-accredited group was higher at 39.32 when compared to the $\mathrm{C}$-accredited group at 36.78. Also, the group B had students with high mathematical proving ability of $12.5 \%$ and the rest were in the low category, while in the group $\mathrm{C}$, there was no student in the high category. It was only $3.45 \%$ of students were in the intermediate category and the remaining $96.55 \%$ were in the low category. From these results, the mathematical proving ability of students in the $\mathrm{B}$-accredited university is better than the $\mathrm{C}$-accredited university though the difference is not significant.

Related to the results of this comparison, we could suggest to lecturers and university management, especially in B and C-accredited universities, to work on improving facilities and infrastructures supporting the learning process, such as providing free internet services on campus, completing library facilities, learning media, and comfortable classrooms for learning.

\section{Conclusions}

Based on the results of this study, we found that the students' average score of mathematical proving ability in the $\mathrm{A}, \mathrm{B}$, and $\mathrm{C}$-accredited universities were respectively 77.14 (high category), 39.32 (low category), and 36.78 (low category). Further, we compared the students' mathematical proving ability, and found that there were significant differences of the ability between the students in $\mathrm{A}$ and $\mathrm{B}$-accredited universities and between $\mathrm{A}$ and $\mathrm{C}$-accredited universities. Meanwhile, there was no significant difference of the ability between $\mathrm{B}$ and $\mathrm{C}$ accredited universities. Based on the results, we can also conclude that the students' mathematical proving ability in $\mathrm{B}$ and $\mathrm{C}$-accredited universities were in low category. Thus, it still needs to be improved.

The difficulties experienced by the students of A-accredited university in solving problems involving mathematical proof could also be identified, including the lack of students' ability to determine the form of identity element and inverse element in group proving problems, the students' carelessness who often forget to write the required conditions completely in solving subgroup proving problems then it resulted in incorrect conclusion. Meanwhile, the difficulties experienced by the students in $\mathrm{B}$ and $\mathrm{C}$-accredited universities include the inability to identify enough concepts to prove, the errors to determine the initial steps and choose strategies to use in proving process, the lack of understanding intuition of the needed concepts, the inadequacy of concept images to run the proving process, and the lack knowledge on how to use definitions, axioms, or theorems to get a comprehensive proof structure.

Based on the results, we could recommend to improve the students' mathematical proving ability in the abstract algebra course by making the students accustomed to practicing with proving problems, giving reinforcement of initial knowledge related to the concepts learned, motivating the students to learn, and providing a learning handout which is easy to understand. Furthermore, we also recommend to the $\mathrm{B}$ and $\mathrm{C}$-accredited private universities to improve the learning facilities.

\section{Acknowledgments}

Our gratitude goes to The Ministry of Research, Technology and Higher Education of Indonesia who has funded this research through the scheme of Interagency Higher Cooperation Research Grant (PKPT) funding year of 2019 based on the research contract number 01/KP-PKPT/LPPM/UNRIKA/V/2019.

\section{REFERENCES}

[1] Agustyaningrum, N., Abadi, A. M., Sari R. N., \& Mahmudi, A. (2018). An analysis of students' error in solving abstract algebra tasks. Journal of Physics: Conference Series, 1097(1), 012118.

[2] Alcock, L. \& Simpson, A. P. (2002). Definition: Dealing with categories mathematically. For the Learning of Mathematics, 22(2), 28-34.

[3] Arnawa, I. M. (2006). Meningkatkan kemampuan pembuktian mahasiswa dalam aljabar abstrak melalui pembelajaran berdasarkan teori APOS. Dissertation. 
Bandung: Universitas Pendidikan Indonesia.

[4] Arnawa, I. M., Yerizon, \& Enita, S. (2019). Improvement students' level of proof ability in abstract algebra through APOS theory approach. International Journal of Scientific \& Technology Research, 8(7), 128-131.

[5] Asiala, M., Dubinsky, E., Mathews, D.W., Morics, S., \& Oktac, A. (1997). Development of students' understanding of cosets, normality, and quotient groups. Journal of Mathematical Behavior, 16, 241- 309.

[6] Ball, D. L., Hoyles, C., Jahnke, H. N., \& Hadar, N. M. (2002). The teaching of proof. Proceedings of the ICM (vol 3, pp. 907-920). Beijing: ICM.

[7] Barnard, T. (2000). Why are proofs difficult? The Mathematical Gazette, 84(501), 415-422.

[8] Carlson, D. (2003). The teaching and learning of tertiary algebra. Seminar Nasional Aljabar dan Pengajaran Aljabar di Perguruan Tinggi. Yogjakarta.

[9] Chamundeswari, S. (2014). Conceptual errors encountered in mathematical operations in algebra among students at the secondary level. International Journal of Innovative Science, Engineering \& Technology, 1(8), 24-38.

[10] Cyr, S. (2013). Development of beginning skills in proving and proof-writing by elementary school students. Retrieved from: www.cerme7.univ. rzeszow.pl/WG/1/Cerme7_WG1_Cyr.pdf.

[11] Enu, J., Agyman, Osei K., \& Nkum, D. (2015). Factors influencing students' mathematics performance in some selected colleges of education in Ghana. International Journal of Education Learning and Development, 3(3), 68-74.

[12] Fadilah, S., \& Jamilah. (2016). Pengembangan bahan ajar struktur aljabar untuk meningkatkan kemampuan pembuktian matematis mahasiswa. Cakrawala Pendidikan, $35(1)$, 106-113.

DOI: https://doi.org/10.21831/cp.v1i1.8379

[13] Findel, B. R. (2001). Learning and understanding in abstract algebra. Dissertation. New Hampshire.

[14] Guler, G. (2016). The difficulties experienced in teaching proof to prospective mathematics teachers: Academician views. Higher Education Studies, 6(1), 145-158.

[15] Hamdi, S., \& Abadi, A. M. (2014). Pengaruh motivasi, self-efficacy dan latar belakang pendidikan terhadap prestasi matematika mahasiswa PGSD STKIP-H dan PGMI IAIH. Jurnal Riset Pendidikan Matematika, 1(1), 77-87.

[16] Hanna, G., \& Jahnke, H. N., (1996). Proof and proofing. In: Bishop A.J., Clements, K., Keitel C., Kilpatrick J., Laborde C. (eds) International handbook of mathematics education. Kluwer international handbook of mathematics handbooks of education, vol 4. Springer, Dordrecht.

[17] Hanna, G., Jahnke, H. N., \& Pulte, H. (2010). Explanation and proof in mathematics. New York: Springer.

[18] Harel, G., \& Sowder, L. (2007). Towards a comprehensive perspective on proof. In F. Lester (Ed.), Second handbook of research on mathematical teaching and learning (pp. 805-842). Washington, DC: NCTM.
[19] Hart, E. W. (1994). A conceptual analysis of the proof-writing performance of expert and novice students in elementary group theory. In J. J. Kaput \& Ed Dubinsky (Eds.). Research Issues in Undergraduate Mathematics Learning. Washington: American Mathematical Society.

[20] Isnarto. (2014). Kemampuan konstruksi bukti dan berpikir kritis matematis mahasiswa pada perkuliahan struktur aljabar melalui guided discovery learning pendekatan motivation to reasoning and proving tasks. Dissertation. Bandung: Universitas Pendidikan Indonesia.

[21] Knuth, E. J. (2002). Secondary school mathematics teachers' conceptions of proof. Journal for Research in Mathematics Education, 33(5), 379-405.

[22] Kusnandi. (2008). Pembelajaran matematika dengan strategi abduktif-deduktif untuk menumbuhkembangkan kemampuan membuktikan pada mahasiswa. Disertation. Bandung: Universitas Pendidikan Indonesia.

[23] Leron, U., \& Dubinsky, E. (1995). An abstract algebra story. The American Mathematical Monthly, 102, 227- 242.

[24] Maharaj, A. (2010). An APOS analysis of students' understanding of the concept of a limit of a function. Pythagoras, 71, 41-52.

[25] Mairing, J. P. (2016). Kemampuan siswa kelas VIII dalam memecahkan masalah matematika berdasarkan tingkat akreditasi. Jurnal Kependidikan, 46(2), 179-192.

[26] Maya, R., \& Sumarmo, U. (2011). Mathematical understanding and proving abilities: experiment with undergraduate student by using modified Moore learning approach. Journal on Mathematics Education, 2(2), 231-250.

[27] Moore, R. C. (1994). Making the transition to formal proof. Educational Studies in Mathematics, 27(3), 249-266.

[28] Nisa, E. K. (2018). Analisis pengaruh akreditasi program studi terhadap intensitas belajar dan harapan masa depan. Jurnal At-Taqaddum, 10(2), 201-218.

[29] Nguyen, H. C., \& Ta, T. T. H. (2017). Exploring impact of accreditation on higher education in developing countries: A Vietnamese view. Tertiary Education and Management, 24(2), 154-167.

DOI:https://doi.org/10.1080/13583883.2017.1406001

[30] Ozdemir, E. \& Ovez, F. T. D. (2012). A research on proof perceptions and attitudes towards proof and proving: some implications for elementary mathematics prospective teachers. Procedia-Social and Behavioral Sciences, 46, 2121-2125.

[31] Reid. D. A. (2005). The meaning of proof in mathematics education. Proceedings CERME3 (pp. 458-468). Bellaria: CERME.

[32] Saefudin, A. A. (2012). Pengembangan kemampuan berpikir kreatif siswa dalam pembelajaran matematika dengan pendekatan Pendidikan Matematika Realistik Indonesia (PMRI). Jurnal Al-Bidayah, 4(1), 37-48.

[33] Samparadja, H. (2014). Pengaruh pendekatan induktif-deduktif berbasis definisi termodifikasi dalam pembelajaran stuktur aljabar terhadap peningkatan kemampuan pembuktian dan disposisi berpikir kreatif matematis mahasiswa. Dissertation. Bandung: Universitas 
Pendidikan Indonesia.

[34] Santosa, C. A. H. F. (2013). Mengatasi kesulitan mahasiswa ketika melakukan pembuktian matematis formal. Jurnal Pengajaran MIPA, 18(2), 152-160.

[35] Selden, A., \& Selden, J. (2003). Validations of proof considered as texts: Can undergraduates tell whether an argument proves a theorem? Journal for Research in Mathematics Education, 34(1), 4-36.

[36] Selden, A., \& Selden, J. (2009). Teaching proving by coordinating aspects of proofs with students' abilities. In Teaching and learning proof across the grades: A K-16 perspective (pp. 339-354). Reston, VA: NCTM.

[37] Sriraman, B. (2004). Gifted ninth graders' notions of proof: Investigating parallels in approaches of mathematically gifted students and professional mathematicians. Journal for the Education of the Gifted, 27(4), 267-292.

[38] Stefanowicz, A. (2014). Proofs and mathematical reasoning. Birmingham: University of Birmingham.

[39] Stout, L. N. (2014). How to study mathematics. Retrieved from: http://sun.iwu.edu/ /stout/How ToStudy.html.

[40] Stylianides, G. J., Stylianides, A. J., \& Philippou, G. N. (2007). Preservice teachers' knowledge of proof by mathematical induction. Journal of Mathematics Teacher Education, 10(3), 145-166.

[41] Stylianides, A., \& Stylianides, G. J. (2008). Cognitive conflict as a mechanism for supporting developmental progressions in student's knowledge about proof. International Congress on Mathematics Education-11. Monterrey: ICME.

[42] Syaiful, Marsal, J. \& Kamid (2016). Development of student comprhension in constructing line and row: Analyzed from APOS theory. ASIO Journal of Chemistry, Physics, Mathematics \& Applied Sciences (ASIO-JCPMAS), 1(2), 5-9.

[43] Tall, D., Yevdokimov, O., Koichu, B., Whiteley, W., Kondratieva, M., \& Cheng, Y.H. (2011). The cognitive development of proof. In Hanna, G., \& De Villiers, M. (Eds). ICMI 19: Proof and Proving in Mathematics Education, pp.13-49.

[44] Toraman, Ç., Özdemir, H. F., Aytuğ Koşan, A. M., \& Orakc1, Ş. (2020). Relationships between cognitive flexibility, perceived quality of faculty life, learning approaches, and academic achievement. International Journal of Instruction, 13(1), 85-100. DOI:https://doi.org/10.29333/iji.2020.1316a.

[45] Tucker, T. W. (1999). On the role of proof in calculus courses. Contemporary Issues in Mathematics Education, $36,31-35$.

[46] Weber, K. (2001). Student difficulty in constructing proofs: The need for strategic knowledge. Education Studies in Mathematics, 48, 101-119.

[47] Weber, K. (2003). Students' Difficulties with Proof. Available at: http://www.maa.org.

[48] Weber, K. \& Alcock, L. (2004). Semantic and syntactic proof production. Educational studies in mathematics, 56(2-3), 209-234.
[49] Yerizon. (2011). Peningkatan kemampuan pembuktian dan kemandirian belajar matematik mahasiswa melalui pendekatan M-APOS. Dissertation. Bandung: Universitas Pendidikan Indonesia.

[50] Yerizon, Arnawa. I. M., Yanita, Ginting, B. \& Nita, S. (2019). Students' errors in learning elementary group theory: A case study of mathematics students at Andalas University. Universal Journal of Educational Research, 7(12), 2693-2698. 